\title{
Heterogeneity of Xanthomonas campestris pv. hederae Strains from Araliaceous Hosts
}

\author{
D. J. Norman, A. R. Chase, R. E. Stall, and J. B. Jones
}

First author: Plant Pathology Department, University of Florida, Central Florida Research and Education Center, Apopka 32703; second author: Chase Research Gardens, Inc., Mt. Aukum, CA 95656; third and fourth authors: Plant Pathology Department, University of Florida, Gainesville 32611. Accepted for publication 29 April 1999.

\begin{abstract}
Norman, D. J., Chase, A. R., Stall, R. E., and Jones, J. B. 1999. Heterogeneity of Xanthomonas campestris pv. hederae strains from araliaceous hosts. Phytopathology 89:646-652.

Xanthomonas campestris pv. hederae (synonym X. hortorum pv. hederae) strains (59 total) were collected from plants in the araliaceae family. Strains were isolated from Hedera helix, Schefflera arboricola, Brassaia actinophylla, and Polyscias spp. from Florida, California, Hawaii, and New Zealand. All strains produced yellow mucoid growth; hydrolyzed esculin, starch, casein and gelatin; were pectolytic; produced urease; and grew on minimal media containing asparagine. All bacterial strains were pathogenic on $H$. helix (English ivy), B. actinophylla (dwarf schefflera), and Polyscias fruticosa (ming aralia). No differences in symptomatology were detected among strains; however, severity of symptoms usually was greatest on the host of origin. In planta growth rates of representative strains isolated from $H$. helix, B. actinophylla, and Polyscias spp. also

more rapidly when strains were inoculated to their original host species. All 59 bacterial strains were compared by 95 -carbon source GN microplate, fatty acid methyl ester (FAME), and restriction fragment-length polymorphisms (RFLP), with the pulse-field gel electrophoresis method, analyses. All three analyses grouped strains into two distinct groups that correlated with the host of origin. Using metabolic profiles, $75 \%$ of the $H$. helix strains were separated from strains isolated from Brassaia and Schefflera and $95 \%$ of the Polyscias strains. FAME analysis separated strains into two distinct groups, with $96 \%$ of the H. helix strains placed in one group. RFLP analysis placed all of the H. helix and Schefflera strains in one group, as well as $33 \%$ of the Brassaia strains, whereas the other group contained all of the Polyscias strains and the remainder of the Brassaia strains. It is apparent that the pathovar hederae is made up of heterogeneous populations that can be separated by biochemical, pathological, genetic, and physiological analyses into two groups that are closely associated with the host of origin.
\end{abstract} were compared among these three hosts. In all cases, populations grew
Plants in the araliaceae family are commonly grown as indoor foliage. The most economically important member of the family is Hedera helix L. (English ivy). Other members include species and cultivars of Dizygotheca, Schefflera, Brassaia, Polyscias, Fatsia, and Fatshedera. Xanthomonas campestris pv. hederae causes serious diseases in all of these plant species. Xanthomonas diseases of $H$. helix and its relatives are characterized by round to angular necrotic lesions bordered by black to purple margins and are sometimes surrounded by a chlorotic halo. Systemic infection has never been demonstrated and does not appear to occur. Serious outbreaks of disease caused by xanthomonads have been reported primarily on Hedera and Polyscias spp., whereas diseases on the remaining araliaceous genera are of little practical concern. Disease incidences as high as $100 \%$ in some greenhouses have been reported for $H$. helix, and most hedgerow plantings of Polyscias spp. in Hawaii are heavily infected with the pathogen.

The pathogen responsible for these diseases on araliaceous plants is $X$. campestris pv. hederae. Vauterin et al. (28) recently proposed that this pathovar be reclassified as $X$. hortorum pv. hederae based on DNA homology, metabolic similarities, and protein profiles. $X$. campestris pv. hederae was originally described in France in 1920 (2). Since that time, $X$. campestris pv. hederae has been reported throughout the world in areas where $H$. helix is grown, including New Zealand (10) and the United States (4,17,30). In 1984, Brassaia actinophylla Endl. (schefflera), Dizygotheca elegantissima

Corresponding author: D. J. Norman; E-mail address: djn@icon.apk.ufl.edu

Florida Agricultural Experiment Station Journal Series R-06367.

Publication no. P-1999-0524-03R

(C) 1999 The American Phytopathological Society
(J.H. Veitch) R. Vig. \& Guillaum (false aralia), Fatsia japonica (Thunb.) Decne. \& Planch. (Japanese aralia), Fatshedera sp., Polyscias fruticosa (L.) Harms (ming aralia), and Schefflera arboricola Hayata (dwarf schefflera) were added to the list of plants susceptible to $X$. campestris pv. hederae (5).

Prior to 1980, most researchers relied on the methods used by Dye (9) to characterize xanthomonads. However, as Dye (9) noted, physiological tests cannot distinguish between pathovars of $X$. campestris. The convention, therefore, has been to name pathovars according to host range (23). Extensive host range studies are prohibitive if multiple plant families are to be represented, so many studies have used only a few genera or species in the same family as the new host, with the result that the information on specific groups of strains is limited. Since the 1970s, new methods have been used to distinguish between strains of $X$. campestris, including monoclonal antibodies (1), restriction fragment-length polymorphism (RFLP) $(13,14)$, fatty acid analyses $(17,18,21,22)$, DNA homology $(12,27,28)$, genomic fingerprinting (6), 16S rRNA characterization (8), and repetitive sequence-based polymerase chain reaction (19, $20)$; the latter two studies $(19,20)$ also addressed the pathovar system developed for xanthomonads.

The intent of our study was to characterize strains of $X$. campestris isolated from three genera of araliaceous plants and to better describe $X$. campestris pv. hederae, as well as validate the inclusion of strains from hosts other than $H$. helix in $X$. campestris pv. hederae. Host range, symptomatology, physiological characteristics, fatty acid profiles, and genomic fingerprinting were studied.

\section{MATERIALS AND METHODS}

Bacterial strains and media. $X$. campestris pv. hederae strains (59 total) were collected from araliaceous plants in Florida, Cali- 
TABLE 1. Sources of Xanthomonas campestris pv. hederae strains from araliaceae hosts

\begin{tabular}{|c|c|c|c|}
\hline Strain & Host of Origin & Source designation $^{\mathrm{x}}$ & $\begin{array}{l}\text { Geographic } \\
\text { source }\end{array}$ \\
\hline $\mathrm{X} 24$ & Schefflera arboricola & PDD-659A-82 (NCPPB3588) & Florida \\
\hline $\mathrm{X} 25$ & Schefflera arboricola & PDD-659B-82 (NCPPB3589) & Florida \\
\hline X37 & Brassaia actinophylla & DPI-083-1335 & Florida \\
\hline X200 & Brassaia actinophylla & GWS-2285B-84 & Florida \\
\hline X261 & Hedera helix & CFRECA-87-48 & Florida \\
\hline $\mathrm{X} 276$ & Hedera helix & CFRECA-87-H2 & Hawaii \\
\hline $\mathrm{X} 284$ & Hedera helix & CFRECA-87-H3 & Hawaii \\
\hline X289 & Brassaia actinophylla & CFRECA-87-90 & Florida \\
\hline $\mathrm{X} 325$ & Hedera helix & CFRECA-87-223A & Florida \\
\hline X381 & Hedera helix & DPI-P87-5572 & Florida \\
\hline X382 & Hedera helix & DPI-P87-5568 & Florida \\
\hline X384 & Hedera helix & NZTCC-1743 & N. Zealand ${ }^{\mathrm{y}}$ \\
\hline $\mathrm{X} 405$ & Hedera helix & NZTCC-453 (PDDCC 453) & N. Zealand \\
\hline $\mathrm{X} 413$ & Hedera helix & NZTCC-1406 (ICMP 1406) & N. Zealand \\
\hline $\mathrm{X} 425$ & Hedera helix & CFRECA-88-22 & Florida \\
\hline X445 & Hedera helix & CFRECA-88-84A & Florida \\
\hline X446 & Hedera helix & CFRECA-88-84B & Florida \\
\hline X524 & Hedera helix & A 2745 & Hawaii \\
\hline X590 & Hedera helix & CFRECA-88-145B & Florida \\
\hline X600 & Hedera helix & DPI-P88-1800 & Florida \\
\hline X685 & Hedera helix & PDD-1894-88 & Florida \\
\hline X727 & Polyscias sp. & PDD-2581-88 & Florida \\
\hline X731 & Polyscias fabian & CFRECA-89-9A & Florida \\
\hline X732 & Polyscias chinensis & CFRECA-89-10A & Florida \\
\hline X883 & Hedera helix & DPI-P90-277-1 & Florida \\
\hline X1223 & Polyscias sp. & GWS-2671A-89 & Florida \\
\hline X1224 & Polyscias sp. & GWS-2353A-89 & Florida \\
\hline $\mathrm{X} 1270$ & Hedera helix & Cooksey-5-1290 & California \\
\hline X1288 & Brassaia actinophylla & DPI-P90-3927 & Florida \\
\hline X1309 & Brassaia actinophylla & DPI-P91-1013 & Florida \\
\hline $\mathrm{X} 1315$ & Polyscias guilfoylei & A1891-87 & Hawaii \\
\hline X1316 & Hedera helix & A 2745 & Hawaii \\
\hline X1317 & Polyscias guilfoylei & A2761 & Hawaii \\
\hline X1319 & Polyscias guilfoylei & A3651-90 & Hawaii \\
\hline X1320 & Polyscias guilfoylei & A3703-90 & Hawaii \\
\hline X1321 & Polyscias guilfoylei & A3704-90 & Hawaii \\
\hline X1322 & Polyscias guilfoylei & A3705-90 & Hawaii \\
\hline X1324 & Polyscias guilfoylei & A3707-90 & Hawaii \\
\hline X1325 & Polyscias guilfoylei & A3708-90 & Hawaii \\
\hline X1326 & Polyscias guilfoylei & A3709-90 & Hawaii \\
\hline X1327 & Polyscias guilfoylei & A3710-90 & Hawaii \\
\hline X1328 & Polyscias guilfoylei & A3711-90 & Hawaii \\
\hline X1329 & Polyscias guilfoylei & A3712-90 & Hawaii \\
\hline X1330 & Polyscias guilfoylei & A3808-91 & Hawaii \\
\hline X1331 & Polyscias guilfoylei & A3809-91 & Hawaii \\
\hline X1332 & Polyscias guilfoylei & A3810-91 & Hawaii \\
\hline X1333 & Polyscias guilfoylei & A3811-91 & Hawaii \\
\hline X1340 & Hedera helix & DPI-P91-1900 & Florida \\
\hline X1387 & Polyscias balfouriana & CFRECA-91-129 & Florida \\
\hline X1388 & Polyscias balfouriana & CFRECA-91-130 & Florida \\
\hline X1398 & Brassaia actinophylla & DPI-P91-5459 & Florida \\
\hline X1418 & Hedera helix & CFRECA-92-16 & Florida \\
\hline X1419 & Hedera helix & CFRECA-92-17 & Florida \\
\hline X1437 & Hedera helix & CFRECA-92-31 & Florida \\
\hline X1440 & Hedera helix & CFRECA-92-35 & Florida \\
\hline X1443 & Hedera helix & CFRECA-92-39 & Florida \\
\hline X1451 & Hedera helix & CFRECA-92-65A & Georgia \\
\hline X1452 & Hedera helix & CFRECA-92-65B & Georgia \\
\hline X1466 & Hedera helix & CFRECA-92-99 & Oregon \\
\hline
\end{tabular}

${ }^{x} \mathrm{~A}=\mathrm{A}$. Alvarez, Department of Plant Pathology, University of Hawaii at Manoa, Honolulu; CFRECA = A. Chase, University of Florida, Central Florida Research and Education Center, Apopka; Cooksey = D. Cooksey, University of California, Riverside; DPI = J. Miller, Division of Plant Industry, Florida Department of Agriculture and Consumer Services, Gainesville; GWS = G. Simone, Department of Plant Pathology, University of Florida, Gainesville; NZTCC = New Zealand Type Culture Collection, Auckland; PDD = D. Brunk, Plant Disease Diagnostics, Inc., Apopka, FL; NCPPB = National Collection of Plant Pathogenic Bacteria, Harpenden, England.

y New Zealand.

${ }^{\mathrm{z}}$ Pathovar reference strain for $X$. campestris pv. hederae. fornia, Hawaii, and New Zealand. Each was tentatively assigned to a strain group according to the host genus from which it was originally isolated. Strains were stored in $50 \%$ glycerol-nutrient broth at $-70^{\circ} \mathrm{C}$. All strains were grown on Bacto (Difco Laboratories, Detroit) nutrient agar amended with $0.5 \%$ sucrose (NAS). Physiological tests, including starch hydrolysis (17), pectolytic activity (7), growth in asparagine medium, urease production, and esculin, casein, and gelatin hydrolysis (15), were used to confirm identification.

Host range and symptomatology. Inocula for physiological and pathogenicity tests were prepared from 48-h-old NAS cultures grown at $29 \pm 1{ }^{\circ} \mathrm{C}$. Inocula for pathogenicity tests were prepared by suspending bacteria in $0.01 \mathrm{M} \mathrm{MgSO}_{4}$ adjusted to $1 \times 10^{8} \mathrm{CFU} / \mathrm{ml}$ with a spectrophotometer $\left(A_{600 \mathrm{~nm}}\right)$. Inocula were used within $30 \mathrm{~min}$ of preparation.

All plants used in host range and symptomatology tests were obtained from commercial growers as rooted cuttings or tissuecultured plantlets and established in plastic pots containing a peatpine bark medium (1:1 [vol/vol], Canadian peat/pine bark). The medium was steam-treated for $1.5 \mathrm{~h}$ at $90^{\circ} \mathrm{C}$ and amended with $4.4 \mathrm{~kg}$ of Osmocote $19-6-12,4.0 \mathrm{~kg}$ of dolomitic lime, and $0.9 \mathrm{~kg}$ of micronutrients (Micromax, Grace Sierra Horticultural Products Company, Milpitas, CA) per $\mathrm{m}^{3}$. Plants were grown on a greenhouse bench under a maximum light intensity of $500 \mu \mathrm{mol} \cdot \mathrm{s}^{-1} \cdot \mathrm{m}^{-2}$ and temperature range of 15 to $35^{\circ} \mathrm{C}$. After $12 \mathrm{~h}$ of exposure to intermittent mist for $15 \mathrm{~s}$ every $30 \mathrm{~min}$, plants were inoculated with a bacterial suspension with a Spra-tool (fine mist generated by $\mathrm{CO}_{2}$ propellant, Crown Industrial, Hebron, IL) and loosely enclosed in a plastic bag. Controls treated with $0.01 \mathrm{M} \mathrm{MgSO}_{4}$ were included in each test. Bags were removed $24 \mathrm{~h}$ after inoculation, and plants remained under intermittent mist during daylight hours for 4 to 6 weeks. Symptoms were monitored twice weekly.

Three genera of araliaceous plants were used for host range and symptomatology tests: H. helix (English ivy), B. actinophylla (dwarf schefflera), and $P$. fruticosa (ming aralia). Each strain was included on one plant of each host in at least three experiments. In the first test, for each strain, reisolation from symptomatic tissues was performed on NAS. Symptoms were evaluated according to type and severity; data from each strain and host were averaged. Severity was rated as $1=$ no symptoms; $2=$ slight symptoms $(1$ to 10 lesions $<1 \mathrm{~mm}$ in diameter); $3=$ moderate symptoms (lesions $>1 \mathrm{~mm}$ in diameter on $>25 \%$ of the leaves); and $4=$ severe symptoms (lesions coalescing and causing leaf abscission or covering $>50 \%$ of the leaf surface). Analysis of variance and Tukey's LSD tests were performed on means to determine whether strain source affected host range or symptom expression.

Comparative growth rates in plant tissues. Three strains, one isolated from each of three host genera, were chosen (X261 from H. helix, X1309 from Brassaia, and X1328 from Polyscias) for comparative growth studies. One plant of each host $(H$. helix, $B$. actinophylla, and $P$. fruticosa) was inoculated with each of the three strains by injection-infiltration of a $1 \times 10^{4} \mathrm{CFU} / \mathrm{ml}$ suspension $\left(1 \mathrm{~cm}^{2}\right.$ area on each of 10 mature leaves per plant). Plants

TABLE 2. Virulence ratings of Xanthomonas campestris pv. hederae strains on Brassaia actinophylla, Hedera helix, and Polyscias fruticosa ${ }^{\mathrm{z}}$

\begin{tabular}{lcccc}
\hline \multirow{2}{*}{$\begin{array}{l}\text { Original host } \\
\text { genus }\end{array}$} & $\begin{array}{c}\text { No. of } \\
\text { strains }\end{array}$ & B. actinophylla & H. helix & P. fruticosa \\
\cline { 3 - 5 } Brassaia & 6 & $2.5 \mathrm{a}$ & $1.7 \mathrm{ab}$ & $1.5 \mathrm{~b}$ \\
Hedera & 28 & $2.6 \mathrm{a}$ & $2.9 \mathrm{a}$ & $2.5 \mathrm{a}$ \\
Polyscias & 23 & $2.4 \mathrm{a}$ & $2.2 \mathrm{a}$ & $3.5 \mathrm{~b}$ \\
Schefflera & 2 & $1.5 \mathrm{a}$ & $1.6 \mathrm{a}$ & $1.0 \mathrm{a}$ \\
\hline
\end{tabular}

z Virulence values are averages from three separate experiments with each strain: $1=$ no symptoms; $2=$ slight symptoms $(1$ to 10 lesions $<1 \mathrm{~mm}$ in diameter); $3=$ moderate symptoms (lesions $>1 \mathrm{~mm}$ in diameter on $>25 \%$ of leaves); and $4=$ severe symptoms (lesions coalescing and causing leaf abscission or covering $>50 \%$ of leaf surface). Virulence ratings in rows followed by different letters are significantly different at $P \leq 0.05$ based on Tukey's LSD procedures. 
were placed on a greenhouse bench without overhead misting. Populations were counted after $24 \mathrm{~h}$ and four times at weekly intervals beginning 1 week after inoculation. Symptoms were described prior to each sampling date, and samples were chosen from areas exhibiting the average degree of symptoms for the plant-strain combination. At each sampling, two disks $\left(0.5 \mathrm{~cm}^{2}\right.$ each) were ground together in $2.0 \mathrm{ml}$ of $0.01 \mathrm{M} \mathrm{MgSO}_{4}$ and serially diluted to the appropriate level. Suspensions were transferred to NAS, and the number of colonies per plate was counted after 3 to 5 days. Five duplicate plates were used for each dilution at each sampling date. The experiment was performed three times.


Fig. 1. Growth in planta of three strains of Xanthomonas campestris pv. hederae from araliaceous Hedera helix, Brassaia actinophylla, and Polyscias fruticosa plants, respectively. Data is representative of one experiment; similar results were obtained when the experiment was repeated. Strains were originally isolated from H. helix (X261), B. actinophylla (X1309), and P. guilfoylei (X1328).

\section{Dendrogram Distance}



Fig. 2. Dendrogram cluster analysis based on metabolic fingerprints of Xanthomonas campestris pv. hederae strains from araliaceous plants. Individual strains are followed by original host designation: $\mathrm{H}=$ Hedera helix, $\mathrm{B}=$ Brassaia actinophylla, $\mathrm{S}=$ Schefflera arboricola, and $\mathrm{P}=$ Polyscias spp. Strains were placed in two groups: A and B. 
Carbon source oxidation. Strains of $X$. campestris pv. hederae isolated from plants in the araliaceae family were tested for their ability to oxidize carbon sources by the GN microplate system, version 3.5 (Biolog, Hayward CA). Strains were grown for $24 \mathrm{~h}$ on tryptic soy agar (Difco) at $29 \pm 1{ }^{\circ} \mathrm{C}$. Bacteria were suspended in sterile saline $(0.85 \% \mathrm{NaCl})$ to a final optical density $\left(\mathrm{OD}_{590}\right)$ between 0.175 and 0.20 . Microtiter plates were inoculated with $150 \mu \mathrm{l}$ of bacterial suspension per well, incubated at $29 \pm 1^{\circ} \mathrm{C}$ for $48 \mathrm{~h}$, and $\mathrm{OD}$ was recorded and compared to the Biolog database. Using the Biolog dendrogram cluster analysis option, strains were separated based on metabolic profiles.

Fatty acid analysis. Fatty acid methyl ester (FAME) analyses were performed on the 59 bacterial strains by the Microbial Identification System (MIDI), version TSBA 3.90 (Microbial ID, Inc., Newark, DE). Strains were grown for $24 \mathrm{~h}$ at $27 \pm 1^{\circ} \mathrm{C}$ on tryptic soy broth (BBL) amended with Bacto agar (15 g/liter). After $24 \mathrm{~h}$ of growth, $\approx 40 \mathrm{mg}$ of bacterial cells (wet weight) was placed in $13 \times 100$-mm glass tubes fitted with fluorocarbon resin-lined screw caps. Cellular fatty acids were extracted and derivatized to their FAME profiles by procedures described by Miller (16); FAME profiles were statistically compared with the MIDI TSBA 3.90 library $(21,22)$. Three controls were used in fatty acid extraction: (i) reagent; (ii) Stenotrophomonas maltophilia (strain X1128, because of multiple peaks, was used to evaluate the extraction process); and (iii) Xanthomonas campestris pv. begoniae (strain X1271 was used as a check to confirm specificity of analysis to pathovar level). Using the MIDI dendrogram cluster analysis option, strains were grouped based on similarities in FAME profiles.

RFLP. Pulse-field gel electrophoresis (PFGE) restriction endonuclease analysis of strains was done following the procedures of Egel et al. (11) and Cooksey and Graham (6), with some modifications. Strains were grown in $1.5 \mathrm{ml}$ of nutrient broth (Difco) for 16 to $20 \mathrm{~h}$ on a rotary shaker at $200 \mathrm{rpm}$ at $24^{\circ} \mathrm{C}$. Cells $(5 \times$ $\left.10^{9} \mathrm{CFU} / \mathrm{ml}\right)$ were washed in $1 \mathrm{ml}$ of TE buffer $(10 \mathrm{mM}$ Tris, $1 \mathrm{mM}$ EDTA, pH 8.0) and resuspended in $0.5 \mathrm{ml}$ of TE buffer. An equal volume (wt/vol) of $10 \mathrm{mM}$ Tris (pH 8.0), $10 \mathrm{mM} \mathrm{MgCl} 2,0.1 \mathrm{mM}$ EDTA (pH 8.0), and 1\% low-melt preparative-grade agarose (BioRad Laboratories, Hercules, CA) was added to washed cells. Cells embedded in plugs $(10 \times 20 \mathrm{~mm})$ were lysed and stored as described by Egel et al. (11). A $2 \times 4-\mathrm{mm}$ section of plug was digested with $40 \mathrm{U}$ of $\mathrm{XbaI}$ in $200 \mu \mathrm{l}$ of restriction buffer (Promega, Madison, WI) and used in 10- or 20-well combs (Bio-Rad). Pieces of plugs were placed in wells of $1.0 \%$ Bio-Rad high-strength analytical-grade agarose gel made with $0.5 \times$ TBE (Tris-borate-EDTA) and sealed with $1 \%$ Bio-Rad low-melt preparative-grade agarose solution. The gel was placed in a CHEF DR II unit (Bio-Rad) containing 1.5 liters of $0.5 \times \mathrm{TBE}$ and run at $200 \mathrm{~V}(15 \mathrm{~V} / \mathrm{cm}$ of gel $)$. Pulse intervals were at $4 \mathrm{~s}$ for $1 \mathrm{~h}$ followed by $15 \mathrm{~s}$ for $22 \mathrm{~h}$. Lambda DNA, in 48.5-kb concatamers (Bio-Rad), was used in outside lanes for size markers. Each bacteria strain was scored for the presence or absence of PFGE bands. A dendrogram was constructed based on cluster analysis of similarity coefficients by the unweighted pair-group method with arithmetic averages (UPGMA) and single linkage (25). Analysis was performed using the SIMQUAL and SAHN programs (NTSYS-pc, version 1.8, software package; Exeter Software, Setauket, NY).

\section{RESULTS}

X. campestris pv. hederae strains (59 total) were collected from members of the araliaceae family. The largest number of strains was obtained from H. helix (28 strains) and Polyscias spp. (22 strains); the rest were collected from Brassaia (6 strains) and Schefflera (2 strains) (Table 1). Xanthomonas leaf spot has been reported on $H$. helix since 1920 (2), but the disease has been reported on other members of the araliaceae family only since 1984 (5). The number of strains recovered reflects a continuing, serious disease problem on H. helix, a sporadic problem on Schefflera, Brassaia, and Polyscias spp. in Florida, and a serious problem on Polyscias spp. in Hawaii. All strains produced yellow mucoid growth on NAS; hy-

\section{Group A}

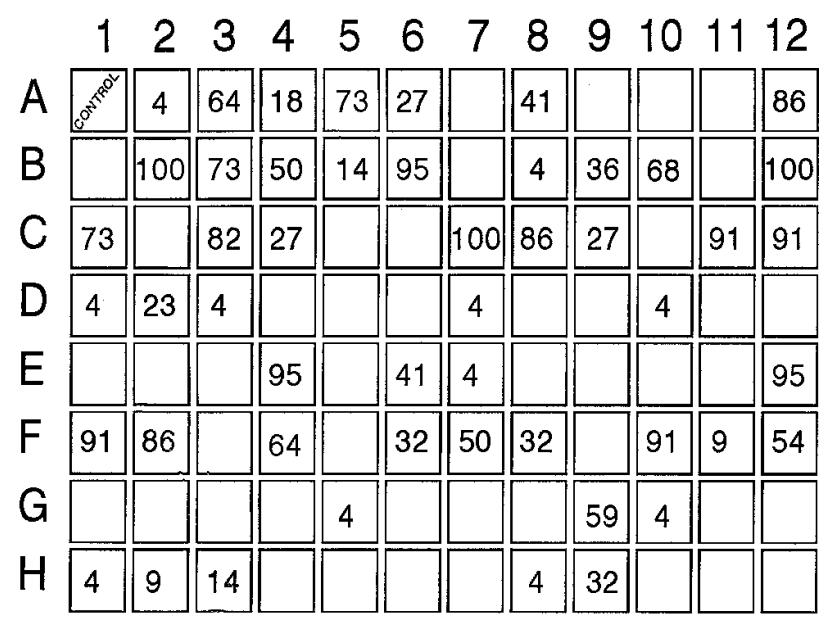

\section{Group B}

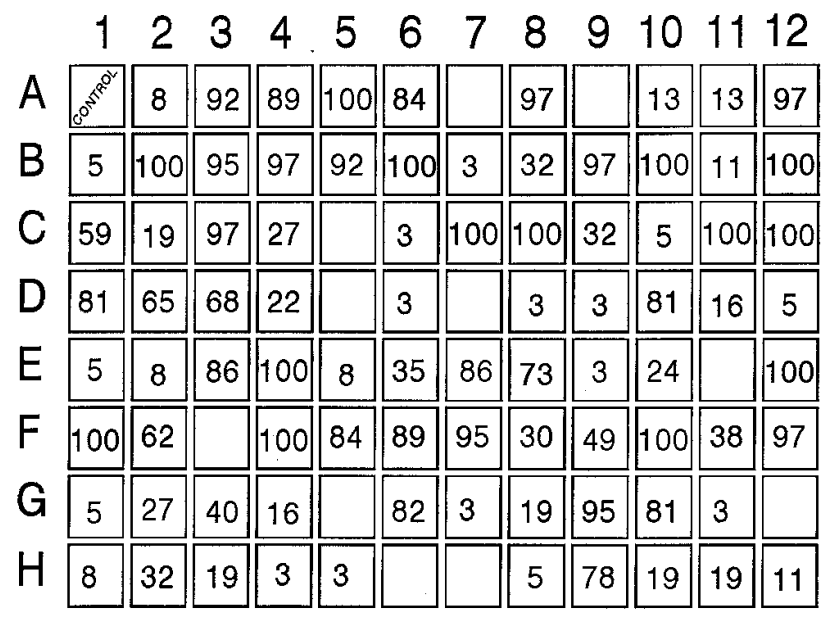

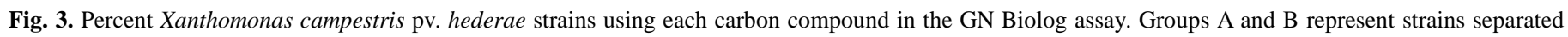



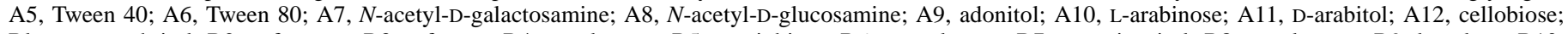

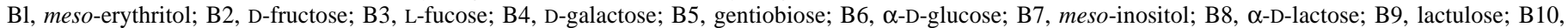

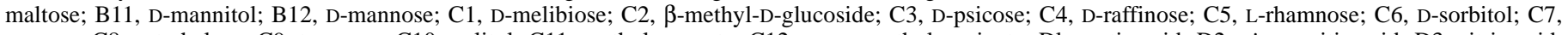





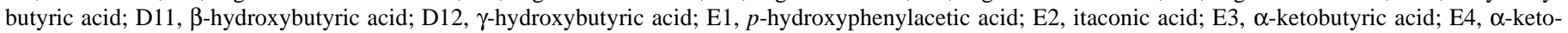

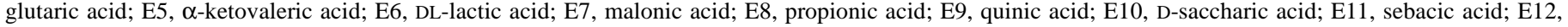

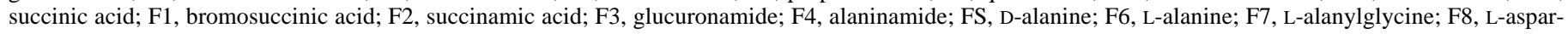

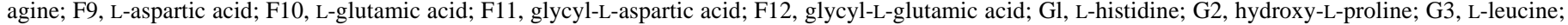

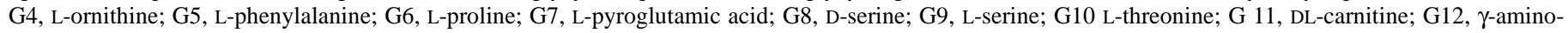

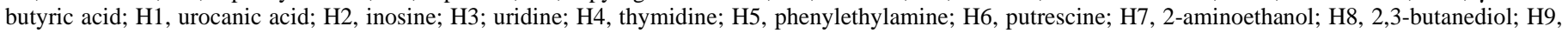
glycerol; H10, DL- $\alpha$-glycerolphosphate; H11, glucose 1-phosphate; and H12, glucose 6-phosphate. 


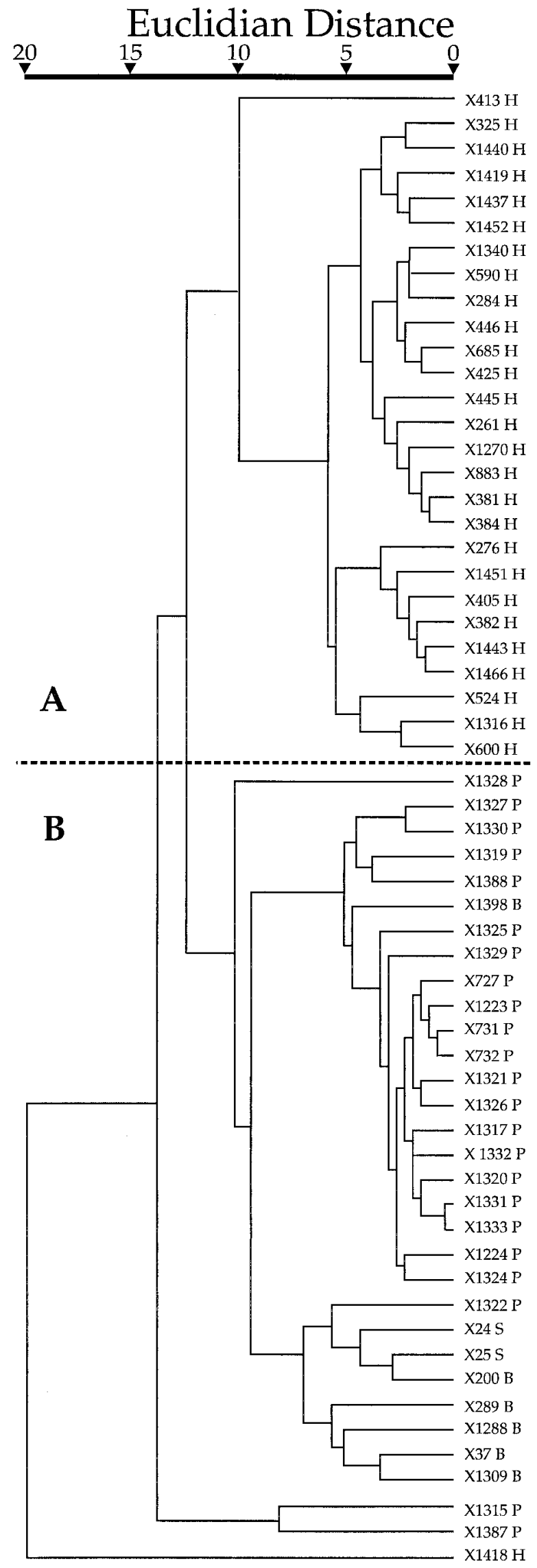

Fig. 4. Dendrogram cluster analysis based on fatty acid methyl ester profiles of Xanthomonas campestris pv. hederae strains from araliaceous plants. Individual strains are followed by original host designation: $\mathrm{H}=$ Hedera helix, $\mathrm{B}=$ Brassaia actinophylla, $\mathrm{S}=$ Schefflera arboricola, and $\mathrm{P}=$ Polyscias $\mathrm{spp}$. Strains were placed in two groups: A and B. drolyzed esculin, starch, casein, and gelatin; were pectolytic; produced urease; and grew on minimal media containing asparagine, which is consistent with their identification as $X$. campestris pv. hederae (3).

Host range and symptomatology. Similar symptoms were produced on the three species of araliaceous plants by all strains. $H$. helix plants developed small water-soaked lesions that were most apparent on the abaxial leaf surface within 7 to 10 days after inoculation. Lesions gradually turned chlorotic and then necrotic and, by 28 days, coalesced sufficiently to cause complete leaf collapse. Leaves $<1 \mathrm{~cm}$ long and fully mature leaves were not susceptible to the pathogen. Similar symptoms occurred on both $B$. actinophylla and $P$. fruticosa. In contrast to $H$. helix, immature leaves of B. actinophylla and $P$. fruticosa were susceptible to the pathogen. Leaf abscission was very common on $B$. actinophylla and $P$. fruticosa, even when $<25 \%$ of the leaf surface was affected. Lesions tended to remain $<1 \mathrm{~mm}$ in diameter on $P$. fruticosa but readily coalesced to include the entire leaf surface. Lesions on B. actinophylla sometimes were similar to those on $P$. fruticosa, but more frequently, they enlarged up to $1 \mathrm{~cm}$ in diameter and generally caused severe leaf abscission.

In general, strains isolated from a particular host were more virulent on that host (Table 2). However, this was not the case with strains from $S$. arboricola, which caused only slight symptoms on $H$. helix, B. actinophylla, and S. arboricola (1.5 disease rating). $H$. helix strains from California, Florida, and Georgia seemed to cause the most severe symptoms on $H$. helix, whereas the four strains from Hawaii caused more severe symptoms when inoculated to Brassaia than to Polyscias. Although Polyscias strains from Hawaii were more virulent on $B$. actinophylla and $H$. helix than strains from Florida, all Polyscias strains caused moderate to severe symptoms on Polyscias (Table 2).

Comparative growth rates in plant tissues. Populations of $X$. campestris pv. hederae increased most rapidly within tissues of plants in the same genera as the original host (Fig. 1). This was most evident with strains inoculated to $H$. helix and $B$. actinophylla and, to a lesser extent, to $P$. fruticosa, in which strain X1328 (isolated from $P$. guilfoylei) grew only slightly more rapidly than the other strains. There were no apparent differences in the appearance of symptoms between the hosts and strains applied. Similar population growth rates were obtained in repeated experiments.

Carbon source oxidation. Using the Biolog dendrogram cluster analysis option, strains were separated based on their metabolic profiles into two distinct groups (Fig. 2). Group A contained 75\% (21 of 28) of the strains isolated from $H$. helix, whereas group B contained all the Brassaia and Schefflera and 95\% (21 of 22) of the Polyscias strains. Strains in group B had diverse metabolic profiles and were capable of using many more carbon sources (Fig. 3). All strains were identified to the genus Xanthomonas; however, at the pathovar level, most strains (81\%, 48 of 59) had similarity indexes (SI) closer to 18 pathovars other than hederae. Strains classified as $X$. campestris pv. hederae (11 strains) had a mean SI = 0.60. Of these strains, $64 \%$ ( 7 of 11 ) were isolated from $H$. helix, and 6 were placed in group A ( $\mathrm{SI} \geq 0.50$ is considered a match in both Biolog and MIDI analyses).

TABLE 3. Seven most common fatty acids $(\%)^{\mathrm{x}}$ in 59 Xanthomonas campestris pv. hederae strains ${ }^{\mathrm{y}}$

\begin{tabular}{lcc}
\hline Fatty acid & Group A (mean \pm SD) & Group B (mean \pm SD) \\
\hline $11: 0$ iso & $3.56 \pm 0.43^{* * \mathrm{z}}$ & $4.20 \pm 1.23^{* *}$ \\
$15: 0$ & $2.98 \pm 1.86^{* *}$ & $1.36 \pm 0.36^{* *}$ \\
$15: 0$ iso & $27.59 \pm 2.81$ & $27.96 \pm 5.12$ \\
$15: 0$ anteiso & $19.18 \pm 1.54^{* *}$ & $9.21 \pm 3.21^{* *}$ \\
$16: 0$ & $4.24 \pm 0.93^{* *}$ & $6.31 \pm 1.92^{* *}$ \\
$17: 1 \omega 9 \mathrm{c}$ iso & $2.90 \pm 0.67^{* *}$ & $5.24 \pm 1.03^{* *}$ \\
$17: 0$ iso & $3.18 \pm 0.49^{* *}$ & $7.46 \pm 1.92^{* *}$ \\
\hline
\end{tabular}

${ }^{x}$ These fatty acids comprise $\approx 63 \%$ of the total strain profiles.

${ }^{y}$ Groups A and B represent strains separated by computer clustering algorithms (Fig. 4).

${ }^{\mathrm{z}}$ Means followed by $* *$ are significantly different at $P=0.05$. 
Fatty acid analysis. FAME extractions and analyses with computer clustering algorithms divided the 59 strains into 2 groups (Fig. 4). Again, group A consisted primarily of strains isolated from H. helix $(96 \%, 27$ of 28), and group B contained the other strains. Only $30 \%$ (18 of 59) of the strains were correctly identified to the pathovar level, with an average SI $=0.73$. All 18 strains were located in group A. Percentages of the most prevalent fatty acids found in the FAME profiles are shown in Table 3.

\section{Similarity}

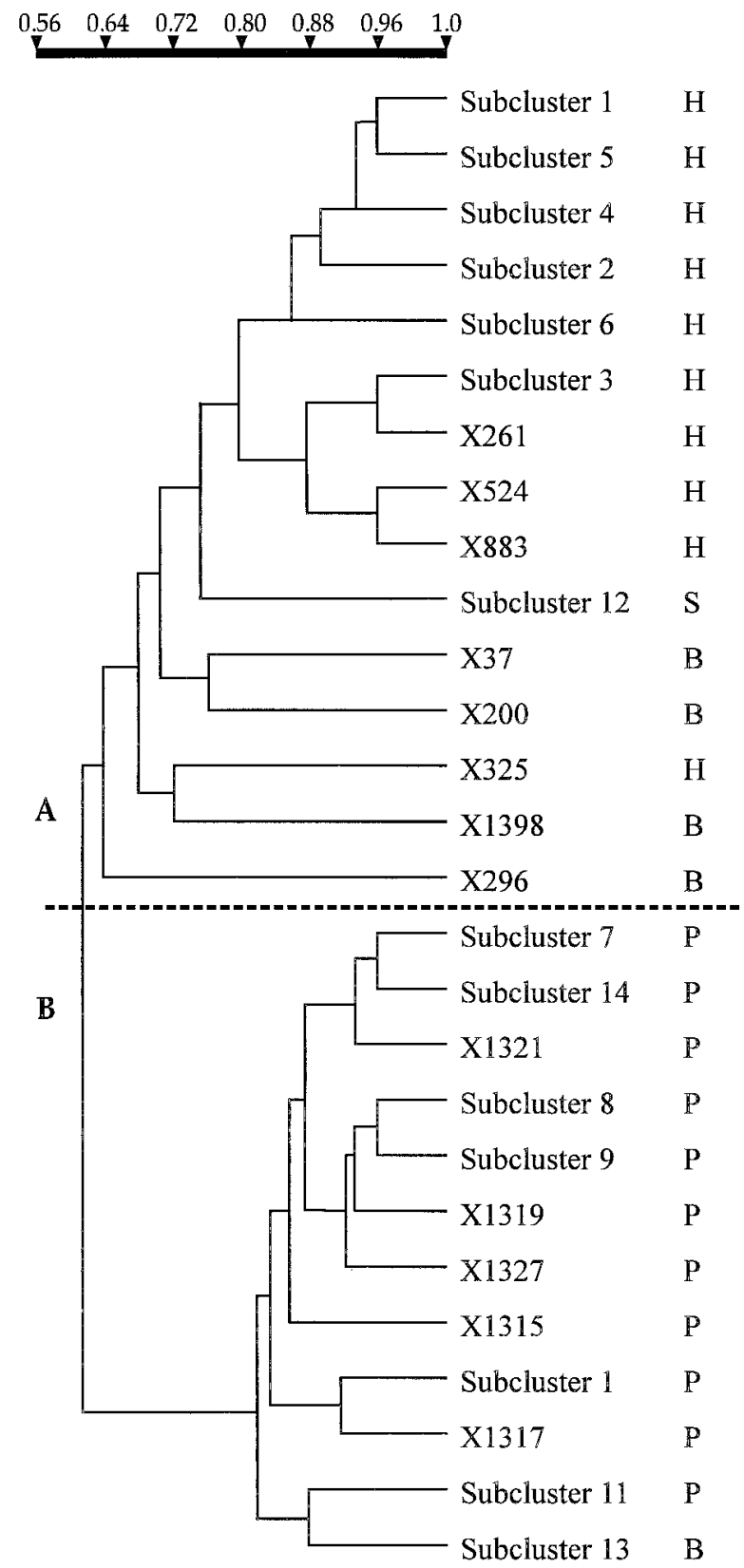

Fig. 5. Dendrogram cluster analysis based on restriction fragment length polymorphism genomic fingerprints of Xanthomonas campestris pv. hederae strains from araliaceous plants. Individual strains are followed by original host designation: $\mathrm{H}=$ Hedera helix, $\mathrm{B}=$ Brassaia actinophylla, $\mathrm{S}=$ Schefflera arboricola, and $\mathrm{P}=$ Polyscias spp. Strains were placed in two groups: A and B. Strains grouped in subclusters: 1: X276, X382, X425, X445, X590, X1437, X1440; 2: X381, X446, X685, X1340, X1443, X1466; 3: X600, X1270, X1316; 4: X284, X1418, X1419; 5: X384, X405, X413; 6: X1451, X1452; 7: X1320, X1322; 8: X1324, X1325; 9: X1326, X1328; 10: X1329, X1330, X1331, X1332, X1333; 11: X727, X731, X732, X1387, X1388; 12: X24, X25; 13: X1288, X1309; and 14: X1223, X1224.
RFLP. Using PFGE and $X b a I$ digestion, 26 bands were resolved between 48.5 to $1,000 \mathrm{~kb}$. The 59 bacterial strains were divided into 27 genomic fingerprints. A dendrogram constructed by UPGMA analysis separated the strains into two distinct groups (Fig. 5). Group A contained $100 \%$ of the strains isolated from $H$. helix, 33\% (four of six) of the Brassaia strains, and both Schefflera strains. Group B contained 100\% (22 of 22) of the Polyscias strains.

\section{DISCUSSION}

The commercial MIDI FAME analysis and Biolog GN microplate systems frequently misidentify bacteria at the pathovar level, so identification of pathovars usually requires some knowledge of the host of origin. Unfortunately, the accuracy of these automated systems depends on the source and number of strains used to develop the computer databases. Poorly defined pathovars that may not represent truly biologically separate entities further confound identification. Both FAME and GN microplate systems were more accurate with strains isolated from $H$. helix than with strains from other sources.

Vauterin et al. (26) in describing proposed species X. hortorum stated that the Biolog GN system could distinguish the hortorum group from other Xanthomonas species, using 16 positive and 27 negative tests. We found that the metabolic fingerprints of the 59 strains we tested were far more complex than Vauterin et al. (26) reported. Strains in group A (Fig. 2), which were isolated from $H$. helix, more closely resembled the nutritionally limited profiles reported by Vauterin et al. (26), whereas strains in group B were capable of using many more carbon sources. Similar results with FAME analysis separated strains into two distinct groups, with strains isolated from $H$. helix in one group and those from Schefflera, Brassaia, and Polyscias in the other. The Euclidean distance for these two groups is $\approx 10$ (Fig. 4), which is considered the minimum level at which species designation can be determined (21). Following this guideline, strains X1315, X1387, and X1418 in group B (Fig. 1) would be considered outliers; however, separation of strains by host was further confirmed by RFLP data that placed these strains within their respective host clusters (Fig. 5).

It is apparent that pathovar hederae is heterogeneous and can be separated into at least two lineages based on FAME, metabolic fingerprint, and RFLP analyses. Furthermore, in planta growth rates and severity of symptoms reflect adaptation to particular araliaceous host species. The heterogeneity of $X$. campestris pv. hederae strains observed in our study suggests that the hederae group should be divided into two pathovars; however, additional research, such as DNA-DNA hybridization $(26,29)$ and extensive host range studies, is necessary before this can be proposed.

The genus Xanthomonas is made up of a diverse group of species that form a continuum with genetic gaps between and within species that expand with time. Schnathorst (24) theorized that closely related pathovars could be induced, by serial passage through alternate hosts, to switch pathovar designation. His attempts to transform pathovars malvacearum, pruni, and translucens into X. campestris pv. phaseoli by seven successive passes through bean plants failed and yielded no apparent increase in virulence. The logical conclusion is that strains of hederae, when associated with a new host on which they are at least somewhat compatible, genetically change over time and adapt to the new host.

Genetic changes within a pathovar most likely occur under conditions in which populations are geographically separated and, in time, may not be reversible. This could be accomplished easily in the ornamental plant industry due to separation in greenhouses, crop movement, and limited host species grown at a particular location. Another explanation for the heterogeneity observed in pathovar hederae is that convergent populations are colonizing similar plant species with indistinguishable symptomatology. Further genetic comparisons need to be made to better define the population. 


\section{ACKNOWLEDGMENTS}

We thank E. R. Dickstein, H. C. Hodge, T. Mellich, P. Strickler, and J. M. F. Yuen for technical assistance on this project.

\section{LITERATURE CITED}

1. Alvarez, A. M., Benedict, A. A., and Mizumoto, C. Y. 1985 Identification of xanthomonads and grouping of strains of Xanthomonas campestris pv. campestris with monoclonal antibodies. Phytopathology 75:722-728.

2. Arnaud, G. 1920. Une maladie bacterienne du lierra (Hedera helix L.) C.R. Hebd. Seances Acad. Sci. Ser. D 171:121-122.

3. Bradbury, J. F. 1984. Genus. II. Xanthomonas Dowson 1939. Pages 199210 in: Bergey's Manual of Systemic Bacteriology. Vol 1. N. R. Krieg and J. G. Holt, eds. Williams and Wilkins, Baltimore.

4. Burkholder, W. H., and Gutterman, C. E. F. 1932. Synergism in a bacterial disease of Hedera helix. Phytopathology 22:781-784.

5. Chase, A. R. 1984. Xanthomonas campestris pv. hederae causes a leaf spot of five species of Araliaceae. Plant Pathol. 33:439-440.

6. Cooksey, D. A., and Graham, J. H. 1989. Genomic fingerprinting of two pathovars of phytopathogenic bacteria by rare-cutting restriction enzymes and field inversion gel electrophoresis. Phytopathology 79:745-750.

7. Cuppels, D., and Kelman, A. 1974. Evaluation of selective media for isolation of soft-rot bacteria from soil and plant tissue. Phytopathology 64: 468-475.

8. DeParasis, J., and Roth, D. A. 1990. Nucleic acid probes for identification of phytobacteria: Identification of genus-specific 16S RNA sequences. Phytopathology 80:618-621.

9. Dye, D. W. 1962. The inadequacy of the usual determinative tests for identification of Xanthomonas spp. N.Z. J. Sci. 4:393-416.

10. Dye, D. W. 1967. Bacterial spot of ivy caused by Xanthomonas hederae (Arnaud, 1920) Dowson, 1939, in New Zealand. N.Z. J. Sci. 10: 481-485.

11. Egel, D. S., Graham, J. H., and Stall, R. E. 1991 Genomic relatedness of Xanthomonas campestris strains causing diseases of citrus. Appl. Environ. Microbiol. 57:2724-2730.

12. Hildebrand, D. C., Palleroni, N. J., and Schroth, M. N. 1990. Deoxyribonucleic acid relatedness of 24 Xanthomonad strains representing 23 Xanthomonas campestris pathovars and Xanthomonas fragariae. J. Appl. Bacteriol. 68:263-269.

13. Lazo, G. R., and Gabriel, D. W. 1987. Conservation of plasmid DNA sequences and pathovar identification of strains of Xanthomonas campestris. Phytopathology 77:448-453.

14. Lazo, G. R., Roffey, R., and Gabriel, D. W. 1987. Pathovars of Xanthomonas campestris are distinguishable by restriction fragment-length polymorphism. Int. J. Syst. Bacteriol. 37:214-221.

15. MacFaddin, J. F. 1981. Biochemical Tests for Identification of Medical
Bacteria. 2nd ed. Williams and Wilkins, Baltimore.

16. Miller, L. T. 1982. Single derivatization method for routine analysis of bacterial whole-cell fatty acid methyl esters, including hydroxy acids. J. Clin. Microbiol. 16:584-586.

17. Norman, D., and Alvarez, A. 1989. A rapid method for presumptive identification of Xanthomonas campestris pv. dieffenbachiae and other xanthomonads. Plant Dis. 73:654-658.

18. Norman, D. J., Chase, A. R., Hodge, N. C., and Stall, R. E. 1997. Differentiation of three species of Xanthomonas and Stenotrophomonas maltophilia using cellular fatty acid analyses. Eur. J. Plant Pathol. 103:687-693.

19. Opgenorth, D. C., Smart, C. D., Louws, F. J., de Bruijn, F. J., and Kirkpatrick, B. C. 1996. Identification of Xanthomonas fragariae field isolates by repPCR genomic fingerprinting. Plant Dis. 80:868-873.

20. Rademaker, J. L. W., Louws, F. J., Schultz, M. H., Rossbach, U., Vauterin, L., Swings, J., and de Bruijn, F. J. 1997. Molecular systematics of xanthomonads by rep-PCR genomic fingerprinting and computer-assisted pattern analysis. (Abstr.) Phytopathology 87(suppl.):S81.

21. Sasser, M. J. 1990. Identification of bacteria through fatty acid analysis. Pages 199-204 in: Methods in Phytobacteriology. Z. Klement, K. Rudolph, and D. Sands, eds. Akademiai Kiado, Budapest.

22. Sasser, M. J. 1990. Identification of bacteria by gas chromatography of cellular fatty acids. Tech. Note 101. Microbial ID, Inc., Newark, DE.

23. Schaad, N. W., ed. 1988. Laboratory Guide for Identification of Plant Pathogenic Bacteria. 2nd ed. American Phytopathological Society, St. Paul, MN.

24. Schnathorst, W. C. 1966. Unaltered specificity in several xanthomonads after repeated passage through Phaseolus vulgaris. Phytopathology 56:5860.

25. Sneath, P. H. A., and Sokal, R. R. 1973. Numerical Taxonomy. W. H. Freeman \& Co., San Francisco.

26. Vauterin, L., Hoste, B., Kersters, K., and Swings, J. 1995. Reclassification of Xanthomonas. Int. J. Syst. Bacteriol. 45:472-489.

27. Vauterin, L., Swings, J., Kersters, K., Gillis, M., Mew, T. W., Schroth, M. N., Palleroni, N. J., Hildebrand, D. C., Stead, D. E., Civerolo, E. L., Hayward, A. C., Maraite, H., Stall, R. E., Vidaver, A. K., and Bradbury, J. F. 1990. Towards an improved taxonomy of Xanthomonas. Int. J. Syst. Bacteriol. 40:312-316

28. Vauterin, L., Vantomme, R., Pot, B., Hoste, B., Swings, J., and Kersters, K. 1990. Taxonomic analysis of Xanthomonas campestris pv. begoniae and $X$. campestris pv. pelargonii by means of phytopathological, phenotypic, protein electrophoretic and DNA hybridization methods. Syst. Appl. Microbiol. 13:166-176.

29. Wayne, L. G., Brenner, D. J., Colwell, R. R., Girmont, P. A. D., Kandler, O., Krichevsky, M. I., Moore, L. H., Moore W. E. C., Murray, R. G. E., Stackebrandt, E., Starr, M. P., and Trüper, H. G. 1987. Report of the Ad Hoc Committee on Reconciliation of Approaches to Bacterial Systematics. Int. J. Syst. Bacteriol. 37:463-464.

30. White, R. P., and McCulloch, L. 1934. A bacterial disease of Hedera helix. J. Agric. Res. 48:807-815. 